\title{
Federal Disclosure Statutes and the Fifth Amendment: The New Status of Trade Secrets
}

In Ruckelshaus v. Monsanto Co., ${ }^{1}$ the Supreme Court held that trade secrets recognized as property by state law are protected from uncompensated disclosure by the takings clause of the fifth amendment. ${ }^{2}$ But the Court also appeared to decide that, if the trade secret has been disclosed to the federal government, this protection attaches only if the disclosure statute that allowed the federal government to learn the secret contains an explicit assurance of confidentiality. If this two-part reading of Monsanto is correct, the decision is both internally inconsistent and in opposition to the Court's other takings clause decisions. Moreover, this interpretation leaves open the unacceptable possibility that a notice statute-informing the public that a certain class of interests previously protected by the law will no longer enjoy such protection-may be used to take, without compensation, property interests in a trade secret that has yet to be created.

Monsanto's first principle-that trade secrets recognized as property by state law are entitled to fifth amendment protection-has important implications for the interpretation of federal disclosure statutes such as the Freedom of Information Act (FOIA). ${ }^{3}$ In interpreting these statutes, the United States Court of Appeals for the District of Columbia Circuit has developed a federal common law definition of trade secrets that is much narrower than that of most states. Thus, under FOIA, the government often discloses trade secret property without compensation. Confidential business information is particularly vulnerable to federal disclosure because of the wide divergence in the way federal common law and state law define nontechnical trade secrets.

This comment scrutinizes the prevailing interpretation of Monsanto, just summarized, in light of fifth amendment jurisprudence and argues that this interpretation is inconsistent and unjus-

467 U.S. 986 (1984).

2 "[N]or shall private property be taken for public use, without just compensation." U.S. Const. amend. V.

35 U.S.C. $\$ 552$ (1982). 
tified. The comment concludes that Monsanto instead should be understood both to protect trade secret property without the requirement of federal statutory validation and to recognize that complete takings pursuant to a notice statute may well be unconstitutional.

This more coherent reading of Monsanto would mandate major changes in the application of FOIA by demanding fifth amendment protections for trade secrets that are recognized as property under state law. Indeed, even under the existing reading of the opinion-conditioning protection on the government's promise of confidentiality - the Monsanto decision compels changes in FOIA disclosure practice so as to avoid violations of the fifth amendment.

\section{The Ruckelshaus v. Monsanto Decision}

In Monsanto, the Court squarely held for the first time that trade secrets may constitute property interests within the meaning of the fifth amendment. In this case, Monsanto Company, a pesticide manufacturer, challenged certain disclosure provisions of the Federal Insecticide, Fungicide, and Rodenticide Act (FIFRA). ${ }^{5}$ FIFRA requires that a pesticide be registered with the Environ-

467 U.S. at 1000-04. Before Monsanto, it was sometimes denied that trade secrets were property, relying on a famous dictum by Justice Holmes:

The word property as applied to trade-marks and trade secrets is an unanalyzed expression of certain secondary consequences of the primary fact that the law makes some rudimentary requirements of good faith. Whether the plaintiffs have any valuable secret or not the defendant knows the facts, whatever they are, through special confidence that he accepted. The property may be denied but the confidence cannot be. Therefore the starting point for the present matter is not property or due process of law, but that the defendant stood in confidential relations with the plaintiffs.

E.I. DuPont de Nemours Powder Co. v. Masland, 244 U.S. 100, 102 (1917). This dictum seems to make rights in trade secrets essentially contractual. But it has not been much followed by state courts. See Roger M. Milgrim, 1 Trade Secrets $\S 1.01[1]$ (1985). The Court in Monsanto distinguished Masland by asserting that Holmes in this passage "did not deny the existence of a property interest; he simply deemed determination of the existence of that interest irrelevant to resolution of the case." 467 U.S. at 1004 n.9. Under this reading, Masland left open the question of property rights in trade secrets. This interpretation is certainly plausible, inasmuch as Masland involved a dispute between private parties in which there was no need to consider whether the trade secret status of the information conferred any rights against the world. By contrast, FIFRA (and FOIA as well) involve agencies of the federal government, where the submitter never stood in any relationship of trust or confidence with the party threatening disclosure. Thus, if the secret is to be protected at all in the FIFRA or FOIA contexts the protection must necessarily partake of one of the primary characteristics of property, the right to exclude others regardless of their previous relationship with the trade secret owner.

s 7 U.S.C. $\S 136$ et. seq. (1982). 
mental Protection Agency (EPA) before it may be sold in interstate or foreign commerce; since it was amended in 1972, the statute also has stipulated that the EPA shall not register a pesticide unless it determines that the pesticide will not cause "unreasonable adverse effects on the environment." The Court held that Monsanto's data on environmental effects constituted a trade secret property right under Missouri law, ${ }^{7}$ and that the property right was protected by the takings clause. ${ }^{8}$ But the Court limited the fifth amendment's protection to data submitted between 1972 and 1978, the period when FIFRA explicitly promised confidentiality. ${ }^{9}$

FIFRA authorizes the EPA to collect data from manufacturers on the health and safety effects of pesticides and to disclose certain elements of that data. Before 1972, the statute had been silent with respect to the EPA's use or disclosure of data submitted to it in connection with an application for registration. In 1972, Congress amended FIFRA to prohibit the EPA from publicly disclosing information that, in its judgment, contained or related to "trade secrets or commercial or financial information," 10 and to permit a submitter of data to identify those parts of the data it considered to be "trade secrets or commercial or financial information." 11 In 1978, Congress refined FIFRA's disclosure provisions to allow the EPA to consider the health and safety information submitted by one manufacturer in the registration process for similar chemicals of another manufacturer. However, the EPA could use these data only after expiration of a ten-year exclusive use period for the submitter. In addition, data submitted after December 31, 1969 , could be used in another company's application for registration for fifteen years after the data were submitted, provided the

${ }^{6}$ Id. $\S 136 a(c)(5)(C),(D)$.

T The district court had found that those data had value to Monsanto beyond their use in connection with a particular license application, and that they would also be valuable to Monsanto's competitors. Monsanto Co. v. Acting Adm., United States E.P.A., 564 F.Supp. 552,560 (E.D. Mo. 1983). The district court found further that much of the data "contains or relates to trade secrets as defined by the Restatement of Torts [section 757] and Confidential, [sic] commercial information." Id. at 562. The court held that Monsanto had property rights in its submitted data, including the right to exclude others from making use of the information, and that the FIFRA provisions in question effected a taking of that property both for private use and without adequate compensation. Id. at 566-67.

${ }^{8}$ Monsanto, 467 U.S. at 1003-04.

Id. at 1011.

107 U.S.C. $\S 136 \mathrm{~h}(\mathrm{~b})$.

11 Id. $\S 136 \mathrm{~h}(\mathrm{a}) 1$. If the EPA and a submitter of data disagreed as to whether or not the data were trade secrets, the submitter was given the right to institute a declaratory judgment action in federal district court. Id. $\$ 136 \mathrm{~h}(\mathrm{c})$. 
applicant compensated the submitter. ${ }^{12}$ Compensation for the data was set by a process of agreement backed by binding arbitration. ${ }^{13}$ The 1978 amendments also provided for disclosure of health, safety, and environmental data to the public notwithstanding the prohibition against disclosure of trade secrets in section $136 \mathrm{~h}(\mathrm{~b}) .^{14}$

In analyzing the takings issue, the Court first determined that Monsanto's trade secrets were property under Missouri law. ${ }^{15}$ Next, it separated the data submissions according to the three pertinent periods-pre-1972, 1972 to 1978, and post-1978-and considered for each period whether the EPA's use of the data from that period in evaluating applications of competing pesticide manufacturers constituted a taking of Monsanto's property.

Concentrating on whether the EPA's use of the data had interfered with "reasonable investment-backed expectations," Court found that the 1978 amendments to FIFRA had eliminated any possible expectation Monsanto could have had that subsequently submitted data would be kept confidential. The amendments, the Court said, put Monsanto on notice that if it chose to submit data pertaining to a new active ingredient after the amendments became effective, the EPA could disclose that data after the statutory ten-year waiting period had elapsed. ${ }^{17}$

For data from the 1972 to 1978 period, by contrast, the Court decided that the explicit guarantee of protection established by the 1972 amendments formed the basis of a reasonable investmentbacked expectation. ${ }^{18}$ However, the Court refused to hold that the government's use of Monsanto's data constituted a taking; such a finding, the Court declared, would be "premature," since no arbi-

12 Id. $\$ 136 \mathrm{a}(\mathrm{c})(1)(\mathrm{d})(\mathrm{ii})$.

13 Id.

14 Id. $\S 136 \mathrm{~h}(\mathrm{~d})$. However, under the 1978 amendments, information that would reveal "manufacturing or quality control processes" or deliberately added inert ingredients may not be disclosed unless "the Administrator has first determined that the disclosure is necessary to protect against an unreasonable risk of injury to health or the environment." Id. $\S 136 \mathrm{~h}(\mathrm{~d})(\mathrm{I})(\mathrm{A}) \cdot(\mathrm{C})$.

${ }^{18}$ Monsanto, 467 U.S. at 1003-04. Several Missouri cases had held that trade secrets were property. See, e.g., Reddi-Wip, Inc. v. Lemay Valve Co., 354 S.W.2d 913, 917 (Mo. App. 1962); Harrington v. National Outdoor Advertising Co., 355 Mo. 524, 532, 196 S.W.2d 786, 791 (1946); Luckett v. Orange Julep Co., 271 Mo. 289, 302-04, 196 S.W. 740, 743 (1917).

${ }^{16} 467$ U.S. at 1005, following the test employed in Pruneyard Shopping Center v. Robins, 447 U.S. 74, 83 (1980), and Penn Central Transportation Co. v. New York City, 438 U.S. 104, 124 (1978).

17 Monsanto, 467 U.S. at 1006-07. Note that if there were no possibility of a reasonable investment-backed expectation when the pre-1972 FIFRA statute was silent on the issue of confidentiality, why should notice of disclosure in the statute be required, or even relevant?

18 Id. at 1011. 
tration had taken place yet regarding the use of the data and the Court thus could not resolve the issue of "just compensation."19 Nevertheless, the Court went on to decide that if the use were held to constitute a taking, it would be of a "public character," despite the fact that the direct beneficiaries were other pesticide manufacturers. The public purpose lay in Congress's goal of making new pesticides available to consumers more quickly by eliminating costly, duplicative health testing. ${ }^{20}$ Since the taking would be for public use, the Court held, Monsanto could not enjoin the EPA's actions: the company's only remedy for disclosure of data submitted between 1972 and 1978 would be a Tucker Act ${ }^{21}$ suit for monetary damages. ${ }^{22}$

Finally, the Court turned to the data submitted before 1972 . Before the 1972 amendments, FIFRA was silent with respect to EPA's use of data. But the Trade Secrets Act ${ }^{23}$ made it a crime for any federal employee to disclose, in any manner not authorized by law, any trade secret information revealed to him during the course of his official duties. In addition, the district court had found that the government's policy before 1970 was to maintain the confidentiality of submitted data unless the submitter consented to disclosure. ${ }^{24}$ Nonetheless, the Court decided that these understandings did not create a reasonable investment-backed expectation that the data would not be disclosed. ${ }^{25}$ The Trade Secrets Act, the Court said, "[was] not a guarantee of confidentiality to submitters of data." 2 The Court observed that the pesticide industry "long has been the focus of great public concern and significant government regulation"; under these circumstances, the "possibility was substantial" that the government would find disclosure of submit-

10 Id. at 1013. For a detailed consideration of the operation of FIFRA's statutory compensation scheme, see Note, Compensating Manufacturers Submitting Health and Safety Data to Support Product Registrations After Ruckelshaus v. Monsanto, 61 Ind. L. J. 189, 202-10 (1986). On the question of what compensation is "just," see Lawrence Blum and David Rubinfeld, Compensation for Takings: An Economic Analysis, 72 Cal. L. Rev. 569 (1984).

20 467 U.S. at 1014-16.

2128 U.S.C. $\$ 1491$ (1982): "The United States Claims Court shall have jurisdiction to render judgment upon any claim against the United States founded either upon the Constitution, or any Act of Congress or any regulation of an executive department, or upon any express or implied contract with the United States, or for liquidated or unliquidated damages in cases not sounding in tort."

22467 U.S. at 1019.

${ }^{23} 18$ U.S.C. $\S 1905$ (1982).

24 Monsanto Co., 564 F.Supp. at 564.

25467 U.S. at 1009.

28 Id. at 1008. 
ted data to be in the public interest. ${ }^{27}$ Accordingly, the Court held that disclosure of data submitted before enactment of the 1972 amendments was not a taking. ${ }^{28}$

\section{The Jurisprudence of the Takings Clause}

The fifth amendment provides in part that "[n]o person shall . . . be deprived of life, liberty, or property, without due process of law, nor shall private property be taken for public use, without just compensation." ${ }^{29}$ Determining whether a particular governmental action is a proscribed "taking" requires consideration of the following questions: (1) whether the affected item is a form of "property" within the purview of the amendment; (2) if so, whether the government action constitutes a "taking" of the property; (3) if there is a taking, whether it is for a "public purpose;"30 and (4) whether "just compensation" has been provided.

\section{A. The Definition of "Property"}

The "property" protected by the takings clause "includes the entire 'group of rights inhering in the citizen's [ownership].' It is not used in the 'vulgar and untechnical sense of the physical thing to which the citizen exercises rights recognized by law. [Instead, it] denote[s] the group of rights inhering in the citizen's relation to the physical thing, as the right to possess, use and dispose of it. ... The constitutional provision is addressed to every sort of interest the citizen may possess." "31

Although the Constitution prohibits the uncompensated taking of private property, it does not itself identify or define the property that is to be protected. Instead, property interests "are created and their dimensions are defined by existing rules or understandings that stem from an independent source such as state law."32 The "rules or understandings" that create the property in-

${ }^{27}$ Id. at 1008-09.

28 Id. at 1010.

29 U.S. Const. amend. V. The guarantee against takings was one of the first provisions of the Bill of Rights to be incorporated into the fourteenth amendment; it applies both to state and to federal governments. See Chicago, Burlington, \& Quincy R.R. v. Chicago, 166 U.S. 226, 239 (1897).

${ }^{30}$ If it is not for a public purpose, a governmental taking is forbidden entirely. See text accompanying notes 54-55 below.

31 Pruneyard, 447 U.S. at 82 n.6, quoting United States v. General Motors Corp., 323 U.S. 373, 377-78 (1945) (citations omitted).

32 Board of Regents v. Roth, 408 U.S. 564, 577 (1972). This is true for property protected under the takings clause as well as for property under the due process clauses of the 
terest may be statutes, ${ }^{33}$ judge-made law, ${ }^{34}$ or even implied state or federal government promises. ${ }^{36}$ In some situations, the federal government, as well as the states, may create property interests. ${ }^{36}$

However, the fact that the federal government may create property interests does not mean that it may abrogate state-created property interests by defining or conditioning property in a certain way. In Pruneyard Shopping Center v. Robins, ${ }^{37}$ the Supreme Court asserted that "as a general proposition ... the United States, as opposed to the several States, [is not] possessed of residual authority that enables it to define 'property' in the first instance." The federal government thus lacks the power to say that its definition of property trumps an already recognized state law property interest. The Court in Monsanto at least recognized this much. In rejecting the EPA's argument that FIFRA simply "preempted" Monsanto's property interest that was recognized under Missouri law, the Court observed:

This argument proves too much. If Congress may "pre-empt" state property law in the manner advocated by EPA, then the Taking Clause has lost all vitality. This Court has stated that a sovereign, "by ipse dixit, may not transform private property into public property without compensation. . . . This is the very kind of thing that the Taking Clause of the Fifth

fifth and fourteenth amendments. In Monsanto itself, the Court used the concept of property enunciated in Roth, a due process case, to define property for purposes of the takings clause. 467 U.S. at 1003.

${ }^{33}$ See, e.g., Logan v. Zimmerman Brush, 455 U.S. 422, 430 (1982) (statutorily created cause of action based on discrimination against the handicapped is a property interest).

34 See, e.g., United States Trust Co. of New York v. New Jersey, 431 U.S. 1, 19 n.16 (1977) (property interests in state common law contract rights).

ss See, e.g., Perry v. Sindermann, 408 U.S. 593, 599-602 (1972) (college professor may have had property interest in continued employment, where even though state school had no formal tenure program, faculty guide suggested that teachers should feel secure in their positions as long as they were performing their jobs satisfactorily).

${ }^{36}$ See, e.g., Mathews v. Eldridge, 424 U.S. 319, 332 (1976) (federal Social Security Act's disability benefits are property); Roth, 408 U.S. at 577-78. For a view somewhat in tension with these cases, see Pruneyard, 447 U.S. at 84 ("as a general proposition . . . the United States, as opposed to the several states, [is not] possessed of residual authority to define property in the first instance").

The Court has recognized as property a wide variety of state-created interests. In addition to trade secrets, these interests include horse trainers' licenses, utility services, disability benefits, a high school education, government employment, a drivers' license, welfare benefits, and even a cause of action itself. See Logan, 455 U.S. at 428,431 , and cases cited therein.

${ }^{37} 447$ U.S. at 84 . Note that Justice Blackmun concurred in the opinion of the Court but dissented as to this one sentence. Id. at 88-89. 
Amendment was meant to prevent."38

Thus Monsanto makes clear that when the federal government imposes a rule interfering with an existing state law property right, the federal action may not simply be passed off as a redefinition of "property" given preeminence by the supremacy clause.

In addition, the nature of the interest claimed, rather than its importance or value, determines whether it is property ${ }^{39}$ "The test for deciding whether a 'property' interest has been created is to examine positive law to see whether the government's discretion has been confined by existing 'rules or understandings.' "40

\section{B. What Constitutes a "Taking"}

In order to decide whether property has been "taken" within the meaning of the fifth and fourteenth amendments, courts examine the nature of the government action regarding the property. The courts have held that the deprivation of the former owner, rather than the accretion of a right or interest to the sovereign, constitutes the taking. "Governmental action short of the acquisition of title or occupancy has been held to amount to a taking . . . if its effects are so complete as to deprive the owner of all or most of his interest in the subject matter."41 A taking can occur if the government destroys property as well as if it possesses or occupies the property for its own use. ${ }^{42}$

The Court often decides whether a taking has occurred by examining the effect that the government action has on the various "sticks" that make up the "bundle of rights" collectively thought

38 Monsanto, 467 U.S. at 1012, quoting Webb's Fabulous Pharmacies, Inc. v. Beckwith, 449 U.S. 155,164 (1980).

30 See, e.g., Roth, 408 U.S. at 570-71: "[T]o determine whether due process requirements apply in the first place, we must look not to the 'weight' but to the nature of the interest at stake."

10 Geoffrey R. Stone, Louis M. Seidman, Cass R. Sunstein, and Mark V. Tushnet, Constitutional Law: Cases and Commentary 908 (1986).

11 General Motors Corp., 323 U.S. at 378 (footnote omitted). See generally Annot., Supreme Court's Views as to What Constitutes "Taking," Within Meaning of Fifth Amendment's Command That Private Property Not be Taken for Public Use Without Just Compensation, 57 L.Ed.2d 1254 (1979 \& Supp. 1985).

${ }^{42}$ For example, where the result of government action was to flood petitioner's real estate, rendering it valueless, the Court held that the property had been taken even though petitioner retained title to the property. Pumpelly v. Green Bay Co., 80 U.S. 166, 177-78 (1871) (construing the takings clause of the Wisconsin constitution, which was nearly identical to that of the federal Constitution). And in General Motors Corp., the Court observed that under the fifth and fourteenth amendments "the deprivation of the former owner rather than the accretion of the right or interest to the sovereign constitutes the taking." 323 U.S. at 378. See also Penn Central, 438 U.S. at 143 (Rehnquist, J., dissenting). 
of as "property." "43 If the property owner loses too many important sticks from his bundle, his property has been taken. However, loss of one or more sticks will not necessarily constitute a taking: " every destruction or injury to property by governmental action has been held to be a 'taking' in the constitutional sense." "44 In other words, not all governmental regulations are takings; it is only when "regulation goes too far" that it will be deemed a taking. ${ }^{45}$

Unfortunately, the Supreme Court has not clearly distinguished permissible regulation from impermissible takings. Indeed, as Professor Sax has pointed out, the Court "has developed the habit of introducing its uniformly unsatisfactory opinions in this area with the understatement that 'no rigid rules' or 'set formula' are available to determine where regulation ends and taking begins." 48 The Court has, however, consistently looked at certain factors in this otherwise ad hoc inquiry. The "character of the governmental action, its economic impact, and its interference with reasonable investment-backed expectations" ${ }^{\prime 47}$ all are important in determining whether a taking has occurred. The Court's takings jurisprudence can best be understood by examining the factual settings of particular cases.

In Pruneyard Shopping Center $v$. Robins, ${ }^{48}$ for example, a shopping center owner appealed a California Supreme Court ruling that supporters of political causes were entitled, under the free speech clause of the state constitution, to distribute literature in the common area of the shopping mall. While the Court recognized that "one of the essential sticks in the bundle of property rights is the right to exclude others," 49 it concluded that the action complained of did not significantly infringe that right by impairing the owner's value or use. Accordingly, it found that no compensable taking had occurred. ${ }^{.0}$

In Kaiser Aetna $v$. United States, ${ }^{51}$ on the other hand, peti-

13 See, e.g., Pruneyard, 447 U.S. at 82. See also Bruce Ackerman, Private Property and the Constitution 26-27 (1977) (noting and criticizing this analysis). (1960).

4 Pruneyard, 447 U.S. at 82, quoting Armstrong v. United States, 364 U.S. 40, 48 (1922).

${ }^{45}$ Pruneyard, 447 U.S. at 83, citing Pennsylvania Coal Co. v. Mahon, 260 U.S. 393, 415

48 Joseph Sax, Takings and the Police Power, 74 Yale L. J. 36, 37 (1964).

${ }^{47}$ Pruneyard, 447 U.S. at 83. See also Connolly v. Pension Ben. Guar. Corp., 106 S.Ct. 1018, 1026 (1986).

48447 U.S. 74 (1980).

19 Id. at 82.

so Id. at 83-84.

s1 444 U.S. 164 (1979). 
tioners had constructed a private marina that they connected with the ocean, thereby making it a "navigable waterway" subject to the federal navigational servitude. ${ }^{82}$ Petitioners charged a fee for the use of the marina. Relying on the navigational servitude, the government tried to create a right of free public access. Here, the "stick" in question-the right to exclude others-was the same as in Pruneyard; but in this case petitioners' pecuniary interests were directly tied to it and, indeed, were virtually worthless without it. The Court concluded that the government's attempt to create a public right of access went "so far beyond ordinary regulation . . . as to amount to a taking."

Pruneyard and Kaiser Aetna thus illustrate how the magnitude of government intrusion on a property right, and the value of the remaining "sticks," are central to the judgment of whether a compensable taking has occurred. Government regulation need not totally destroy a property interest in order to be a taking; if it destroys some rights but leaves others intact, a "partial taking" has occurred. The question of whether compensation is required inevitably depends on an assessment of the relative importance of what remains compared to what was taken.

\section{C. "Public Use"}

Finally, the fifth amendment assumes that property may be taken for public use, provided that "just compensation" is paid, whereas property may never be taken for private use. ${ }^{54}$ The scope

32 A navigational servitude "gives rise to an authority in the Government to assure that such streams [as are subject to the servitude] retain their capacity to serve as continuous highways for the purpose of navigation in interstate commerce." Id. at 177.

ss Id. at 178. The view that regulations under the police power may be compensable takings is often controversial. In Williamson County Regional Planning Commission v. Hamilton Bank of Johnson City, 473 U.S. 172, 105 S.Ct. 3108, 3117 (1985), for example, Justice Blackmun questioned whether such decisions as Monsanto, Kaiser Aetna, and Pruneyard really "meant to refer literally to the Taking Clause of the Fifth Amendment ... for the proposition that regulation may effect a taking for which the Fifth Amendment requires just compensation" and whether "the Fifth Amendment requires the payment of money damages to compensate for such a taking." And in United States v. Riverside Bayview Homes, Inc., 106 S.Ct. 455, 459 (1985), Justice White, speaking for a unanimous Court in a case involving denial of zoning approval for a real estate development, affirmed the traditional view that only very stringent regulation can amount to a compensable taking: "Only when a permit is denied and the effect of the denial is to prevent 'economically viable' use of the land in question can it be said that a taking has occurred." Regulations that result in public disclosure of trade secrets fall in precisely this category because the value of trade secrets rests on an indivisible secrecy "stick." Trade secrets cannot, in other words, be partially taken. See part III below.

${ }^{54}$ In Monsanto, for example, the Court held that because the trade secret property taken was used for public health purposes, no injunction would issue against the taking and 
of "public use" has been held to be coterminous with the very broad "public purpose" of the police power. ${ }^{\text {ss }}$ Therefore, in most regulatory cases it is not difficult to establish that the taking was for a public purpose.

\section{Monsanto: Insufficient Protection of Trade Secrets}

\section{A. Monsanto's Apparent Internal Inconsistency}

As we have seen, the purpose of the takings clause of the fifth amendment is to prevent the federal government from freely converting to public use interests that are recognized as property under current law. The federal government may not accomplish this directly by seizing the property; nor may it accomplish it indirectly by so defining "property" as to abrogate an interest already recognized as property. ${ }^{56}$ Nevertheless, it seems that under Monsanto, trade secrets that are property under state law may not be property for purposes of the fifth amendment. The case implies that state property interests are not protected unless Congress validates them by inserting into any disclosure statute a special protective clause like that contained in FIFRA between 1972 and 1978.57

that the trade secret owner could seek only compensatory damages. Had the taking been for a private purpose, the Court would have enjoined it. 467 U.S. at 1016. However, the government's subsequent retransfer of the property to another private party does not inevitably mean that the taking was for a private use. Even though the trade secrets in Monsanto were used to support the permit applications of other private parties, the taking remained one for a public use because it had a "conceivable public character": it aimed to eliminate duplicative efforts and to streamline the registration process in the safety testing of pesticides. Id. at 1014-15. See also Hawaii Housing Authority v. Midkiff, 467 U.S. 229, 239-43 (1984); Berman v. Parker, 348 U.S. 26, 33 (1954). For a criticism of the Midkiff Court's broad view of the scope of "public purpose," see Note, Containing the Effect of Hawaii Housing Authority v. Midkiff on Takings for Private Industry, 71 Cornell L. Rev. 428 (1986).

${ }^{\mathrm{s}}$ Monsanto, 467 U.S at 1014. But see John A. Humbach, A Unifying Theory for the Just-Compensation Cases: Takings, Regulation and Public Use, 34 Rutgers L. Rev. 243, 28586 (1982) (distinguishing public use from public purpose).

o6 Pruneyard, 447 U.S. at 84 . See also notes $37-38$ and accompanying text above.

${ }^{87}$ Lower courts have interpreted Monsanto in this way. For example, New Jersey State Chamber of Commerce v. Hughey, 600 F.Supp. 606 (D. N.J. 1985) involved the New Jersey Right to Know Act, N.J.S.A. 34:5A-1-31 (West Supp. 1986), which provided for disclosure of the chemical identities of substances used in the workplace if the substances fell within certain classes of materials deemed to be hazardous. Id. at 610-11. The district court recognized that New Jersey law protects trade secrets as property, id. at 627 , but held that the absence of preexisting legislation explicitly protecting trade secrets submitted by registrants under the Right to Know Act prevented registrants from having a protectable property interest in the chemical identities. Id. at 628. For a similar holding, see Manufacturers Ass'n of Tri-County v. Knepper, 623 F.Supp. 1066, 1076 (M.D. Pa. 1985).

In Monsanto itself, Justice O'Connor recognized the absurdity of this aspect of the ma- 
Fifth amendment protection, however, is not contingent upon federal statutory recognition of state law property rights. Such a requirement would subordinate the state property right-the "independent source" that "creates" the right to which fifth amendment protection attaches ${ }^{58}$ - to federal legislation. The Court cannot, without lapsing into incoherence, maintain that federal law cannot preempt state property interests ${ }^{5 \theta}$ and at the same time hold that federal disclosure legislation wipes out such interests when it does not promise protection. The fifth amendment itself promises this protection; thus to offer such a promise in legislation is superfluous, and to require an additional promise before the fifth amendment protections can take effect is unconstitutional.

The Court in Monsanto invoked federal law in order to demonstrate that Monsanto could not have had any reasonable investment-backed expectation of secrecy with respect to data voluntarily submitted before 1972 and after 1978. According to the Court, the fact that during these periods FIFRA required disclos-

jority opinion:

The Court's tacit analysis seems to be this: an expectation of confidentiality can be grounded only on a statutory nondisclosure provision situated in close physical proximity, in the pages of the United States Code, to the provisions pursuant to which information is submitted to the Government. For my part, I see no reason why Congress should not be able to give effective protection to all trade secrets submitted to the Federal Government by means of a single, overarching, trade secrets provision. We routinely assume that wrongdoers are put on notice of the entire contents of the Code, though in all likelihood most of them have never owned a copy or opened a single page of it. It seems strange to assume, on the other hand, that a company like Monsanto, well served by lawyers who undoubtedly do read the Code, could build an expectation of privacy in pesticide trade secrets only if the assurance of confidentiality appeared in Title 7 itself.

Monsanto, 467 U.S. at 1023 (concurring in part and dissenting in part). While Justice O'Connor's extrapolation of the consequences that flow from the majority view is accurate and compelling, her analysis commits the same error as the majority opinion: it assumes that trade secrets are not really protected by the fifth amendment unless some federal statute says that they are.

Both the House of Representatives and the Senate recently passed substantial modifications to the data disclosure provisions of FIFRA, but Congress adjourned without enacting either bill. Both versions attempted to broaden access to safety and health test data, in connection with new provisions establishing substantial criminal penalties for disclosure of the data or use of the data to manufacture pesticides by the requestor. FIFRA Amendments of 1986, S.2792, 99th Cong., 2d Sess. $\S \S 101-02$, in 132 Cong. Rec. S 15,355 (Oct. 6, 1986); FIFRA Amendments of 1986, H.R.2482, 99th Cong., 2d Sess. $\$ \S 101-02$, in 132 Cong. Rec. H 11,172 (Oct. 16, 1986). These proposed amendments reflect increased congressional sensitivity to the problems of trade secret data disclosure under FIFRA, and almost certainly would have supported a "reasonable investment-backed expectation" of secrecy even under the inconsistent reading of Monsanto.

ss Roth, 408 U.S. at 577.

s9 Monsanto, 467 U.S. at 1012. 
ure without promising confidentiality obliterated any expectations of secrecy Monsanto may have had by virtue of the property status of trade secrets under Missouri law. The Court thus either ignored expectations created by state trade secret property rights or assumed that these rights were waived. In addition, the Court overlooked any expectations that may have arisen because of EPA's pre-1972 policy of using the data of one applicant in support of another applicant's registration only when the submitter approved. ${ }^{60}$

Throughout this analysis, the Court looked to the nature of Monsanto's expectations-were they reasonable, in light of federal law?-rather than to the extent of governmental interference with them. Yet the inquiry into "reasonable investment-backed expectations" usually begins only after establishment of the existence of legitimate expectations, and then simply considers the magnitude of the government's intrusion on them. For example, in Penn Central Transportation Co. v. New York City, ${ }^{61}$ the Court held that landmark preservation restrictions on the development of Grand Central Terminal did not constitute a compensable taking because they did not interfere with the owner's reasonable investmentbacked expectations. The Court's analysis first acknowledged that the terminal owner had legitimate expectations in the continued use of his property. ${ }^{62}$ It concluded, however, that these expectations had not been substantially defeated, because the owner could continue to use the property for its current purpose, could develop it in several ways without running afoul of the landmark restrictions, and retained and could transfer the air rights above the station. ${ }^{63}$

In Monsanto, however, the Court transformed the expectations inquiry into one that looks very much like its analysis, in other contexts, of whether there is a property interest in the first place. As we have seen, "property" exists by virtue of a government rule or understanding that creates legitimate expectations of

${ }^{60}$ Id. at 1023 (O'Connor, J., concurring in part and dissenting in part), citing Monsanto Co., 564 F.Supp. at 564. Both the majority and Justice O'Connor recognized that the existence and extent of investment-backed expectations was a question of fact. Id. at $1009 \mathrm{n.14}$ (applying the clearly erroneous standard to the district court's fact finding about expectations); id. at 1021 ( $O^{\prime}$ Connor, J., concurring in part and dissenting in part) (suggesting remand for further factual findings on Monsanto's expectations).

${ }_{61} 438$ U.S. 104 (1978).

4 Id. at 107, 122.

${ }^{6 s}$ Id. at 137. 
entitlement in certain classes of people. ${ }^{64}$ The Court's inquiry in Monsanto into "reasonable investment-backed expectations" looks very similar to this. And although the Court eschewed any suggestion that its decision rested on the notion that federal law had somehow conditioned Monsanto's state law property interests, ${ }^{65}$ its examination of "reasonable investment-backed expectations" suggests otherwise.

This confusion in analysis is especially problematic in light of a more fundamental difficulty with the opinion. The reasonable investment-backed expectation analysis is inappropriate in cases involving takings of property that is indivisible, and that can never be subject to a partial taking. ${ }^{66}$ The "reasonable investmentbacked expectations" test was developed to determine whether partial takings violate the fifth amendment. Indeed, the reasonable expectations test makes little sense in the context of a complete taking: one would scarcely expect a person to invest in a property interest that he could expect to be entirely destroyed by the government. A complete taking therefore must always interfere with reasonable expectations.

The Court first articulated the "reasonable investment-backed expectations" test in Penn Central. In that case, there was no dispute that Grand Central Terminal was property, or that the restrictions interfered with the owner's use of the property to some extent. The question at issue was whether the interference-that is, the partial taking-was sufficiently serious to offend the fifth amendment. ${ }^{\circ 7}$ The Court found that the restrictions did leave the terminal owners with some beneficial uses of their property remaining. Thus, the reasonable investment-backed expectations of the owners had not been totally eliminated. ${ }^{88}$ The Court used interference with expectations as a way of measuring the seriousness of the regulation's partial destruction of the property interest at issue. Similarly, in Monsanto the Court used the same factor-interference with reasonable investment-backed expectations-in analyzing an alleged taking of trade secrets. ${ }^{69}$

64 See notes $32-36$ and accompanying text above.

os Monsanto, 467 U.S. at 1012.

68 Professor Epstein has criticized even the position that this analysis can be applied to partial takings; he indicates that there is no meaningful distinction between partial and complete takings for this purpose. See Richard A. Epstein, Takings: Private Property and the Power of Eminent Domain 155 (1985).

6738 U.S. at 107, 122.

ss Id. at 137.

Bo 467 U.S. at 1004-05. 
In applying this test in Monsanto, however, the Court ignored a vital fact about trade secrets: they cannot be taken partially. In most ordinary takings clause cases, the "bundle of rights" comprising the property interest in question contains several distinguishable "sticks." In Pruneyard, for example, the shopping center owner's sticks included the right to exclude others, but it also included other sticks such as the right of alienation and the right of use. The Court concluded that the minimal interference with the right to exclude caused by the distribution of leaflets in the common area of the mall did not "take" the owner's property. ${ }^{70}$

With trade secrets, however, there can be no minimal interference. The property right consists of only one indivisible stick: the right to protection of the secrecy of the trade secret. ${ }^{71}$ If that stick is compromised, the property has been taken completely.

It might be argued that disclosure of a trade secret does not prevent the owner from continuing to use the secret, and that the "use" stick is separable from the secrecy stick. These arguments, however, mistake the true nature of a trade secret. A trade secret is information "that derives independent economic value ... from not being generally known." With the secrecy lost, the independent economic value is gone-because the advantage it gives the owner over his competitors is gone-and the information is worth no more than any publicly available information. The trade secret is not the information itself, but the extra value the information possesses by virtue of its secrecy.

In Monsanto, the Court recognized that the right to exclude others from knowledge of the secret is "central to the very definition of the property interest." conclusion that follows from this premise: that partial takings of trade secrets are impossible, and that as a result no inquiry into the existence of reasonable investment-backed expectations should have been made. Indeed, the decision suggests that whether disclosure of a trade secret constitutes a taking depends on the use subsequently made of the secret information: the Court remarks

70447 U.S. at 83 ("There is nothing to suggest that preventing appellants from prohibiting this sort of activity will unreasonably impair the value or use of their property as a shopping center.").

"1 This fundamental principle of trade secret law is recognized in every state, even where the state law formally treats trade secrets as a tort cause of action rather than as property. See discussion of state trade secret law at notes 108-23 and accompanying text below.

72 Uniform Trade Secrets Act § 1(4), 14 U.L.A. 541-42 (West 1980).

${ }^{73}$ Monsanto, 467 U.S. at 1011. 
that if the pesticide health data revealed problems that made the product less valuable, its disclosure would not constitute a taking. ${ }^{74}$ Because of the indivisible nature of a trade secret, however, such disclosure would also give competitors the benefit of that knowledge, and any disclosure, whatever its incidental effect on the demand for and market value of the pesticide, is a complete taking of the secret, which is the property. For that reason, FIFRA's disclosure provisions are not analogous to limited zoning regulations, which interfere only partially with the value of the regulated property. An accurate analog to federally mandated disclosure of trade secrets is not a limited zoning regulation enacted pursuant to state law, but a federal statute appropriating as federal property all buildings constructed in a particular state after enactment of the statute. ${ }^{75}$

Because any public disclosure of a trade secret is a complete taking, the recognition of a state law property interest should have ended the Court's fifth amendment analysis. The proper conclusion would have been that disclosure of trade secrets pursuant to the pre-1972 and post-1978 FIFRA provisions, where state law protected those secrets, was a taking within the meaning of the fifth amendment without regard to the existence of investment-backed expectations, and therefore regardless of a promise of confidentiality in any federal statute.

\section{B. Prospective Takings: Trade Secrets as Core Common Law Rights}

1. Prospective takings. One might argue that the Court could have saved Monsanto from incoherence simply by admitting that the federal government can prospectively alter state property rights. Under this theory, the supremacy clause would allow the federal government to preempt or condition a state's definition of certain property interests, but the takings clause would prohibit the government from doing so to interests already in place. Thus, the disclosure of data submitted after 1978 would be permissible

74 Id. at 1012 n.15.

${ }_{75}$ Moreover, in the case of zoning, all property owners benefit (at least theoretically) from such regulations, in the form of enhanced property values. Euclid v. Ambler Co., 272 U.S. 365, 394-97 (1926). But one might argue that a pesticide manufacturer also benefits from such implicit compensation. The ability to market a pesticide both nationally and internationally might be enhanced by regulations that provide some assurances to consumers as to the safety of the pesticide. If this were so, however, pesticide manufacturers would welcome mandatory disclosure pursuant to FIFRA rather than resisting it, as they did in Monsanto. 
because the government had provided notice that such disclosure might occur, preempting expectations based on state law. The disclosure of yet-to-be-created trade secrets therefore would not constitute a taking. But this argument is flawed for several reasons.

First, though the Court recognized that the process of developing commercial pesticides involves a great deal of both money and time ${ }^{76}$ it failed to note that the confidential fruits of developmental research, where the research is undertaken with the expectation that these resulting trade secrets would be protected property, would be "taken." In other words, the Court seemed to assume that any notice prior to registration would be adequate to protect trade secret developers from dissipation of their research efforts-no matter how short the notice was in comparison to the length of time required to develop the secrets involved. ${ }^{77}$ Under this insensitive assumption, a great deal of confidential research and development information not yet fully coalesced, but nonetheless providing competitive advantages and thus deserving of protection as trade secret property, could be taken without compensation. Moreover, in practical terms there is no way in which a notice statute could be enacted so as to avoid taking such property. By definition, the property embodied in ongoing research and development programs is secret; a legislature therefore could not determine how long a waiting period would be necessary before a notice statute could take effect, so as to avoid taking the property.

Second, the indivisible nature of trade secrets ${ }^{78}$ belies the argument that the federal government's announcement that it will disclose yet-to-be-created trade secrets is not a prospective taking. Once the government decides to disclose all trade secrets created after a certain date, those secrets have lost all their value, as has the research invested in developing them. Zoning regulation provides an instructive contrast. A regulation specifying that no buildings above a certain height are to be built in a certain area is not a prospective taking because it compromises only one stick in the bundle of property rights that accompanies land ownership in that area. But in the case of trade secrets, any disclosure by the government of data supplied pursuant to a federal statute is an unconstitutional complete taking, because the only value that inheres in a

${ }^{76}$ Id. at 998 (noting that the district court found typical expenditures to be $\$ 5$ million to $\$ 15$ million for several years, and developmental periods to range from fourteen to twenty-two years).

77467 U.S. at 1023 (O'Connor, J., concurring).

${ }^{78}$ See notes $66-74$ and accompanying text above. 
trade secret lies in its "not being generally known."

2. "Core" common law rights. Even if notice under a disclosure statute is held to be adequate (assuming a court could make such a determination), yet-to-be-created trade secrets still merit protection from disclosure. This protection rests on the fundamental principle of the takings clause that "there are limits on governmental authority to abolish 'core' common-law rights, including rights against trespass, at least without a compelling showing of necessity or a provision for a reasonable alternative remedy.",80 Thus, the government's ability to alter trade secret protection, even prospectively with adequate notice, is limited to the extent that protection of trade secrets is such a "core" common law right.

In Webb's Fabulous Pharmacies, Inc. v. Beckwith, ${ }^{81}$ the Supreme Court found that certain common law rights cannot be taken, even prospectively and pursuant to a notice statute, unless they are taken for a public purpose and just compensation is paid. The statute at issue in Webb's Fabulous Pharmacies provided that "[a]ll interest accruing from moneys deposited [in interpleader actions] shall be deemed income of the office of the clerk of the circuit court."82 The Florida Supreme Court upheld the statute because the deposited funds were "considered 'public money" from the date of deposit until withdrawal; "the statute takes only what it creates"; and "[t]here is no unconstitutional taking because interest earned on the clerk of the circuit court's registry account is not private property."8s

70 See notes 71-72 and accompanying text above. A simple hypothetical may help to show why FIFRA's disclosure provision constitutes a taking and not simply a permissible regulation. Compare Monsanto's loss of its preexisting right to sell pesticides without trade secret disclosure with a heroin producer's loss, from a perfectly permissible prohibition on narcotics sales, of his preexisting right to sell the drug. The heroin statute neutrally prohibits all sales of heroin by anyone. By contrast, the post-1978 FIFRA data disclosures took Monsanto's property and in effect gave it to Monsanto's competitors. Even assuming that use of the data by Monsanto's competitors constituted a public use, 467 U.S. at 1016, this use nevertheless took from Monsanto "something more and different from that which is extracted from other members of the public," Monongahela Navigation Co. v. United States, 148 U.S. 312,325 (1893) - that is, from other pesticide manufacturers. It is as though the heroin statute, instead of prohibiting sales, had taken one producer's heroin and given it to all other producers, who were then allowed to sell it. Such a taking of "something more and different" is the essence of a fifth amendment violation. See, e.g., Armstrong, 364 U.S. at 49 (stating that the "Fifth Amendment's guarantee ... . [is] designed to bar Government from forcing some people alone to bear public burdens, which, in all fairness and justice, should be borne by the public as a whole").

${ }^{80}$ Pruneyard, 447 U.S. at 94 (Marshall, J., concurring).

31449 U.S. 155 (1980).

s2 Fla. Stat. § 28.33 (West 1974).

ss Beckwith v. Webb's Fabulous Pharmacies, Inc., 374 So.2d 951, 952-53 (Fla. 1979). 
The Inited States Supreme Court unanimously reversed. The Court concluded that the principal sum was private property, in which the creditors of the fund had a property interest created by the state law of interpleader. The fact that the creditors' property rights would not mature until judgment did not prevent them from asserting a legitimate claim to the interest realized on the principal in the interim. Accordingly, the Court held:

The earnings of a fund are incidents of ownership of the fund itself and are property just as the fund itself is property. . . . [A] State, by ipse dixit, may not transform private property into public property without compensation, even for the limited duration of the deposit in court. This is the very kind of thing that the Taking Clause of the Fifth Amendment was meant to prevent. ${ }^{84}$

At first glance, this result appears irreconcilable with the multitude of cases that teach that state law defines the limit as well as existence of state law property rights. ${ }^{80}$ The Florida legislature, through legitimate processes, had decided to circumscribe property rights in funds deposited in interpleader actions. Nonetheless, the Court held this decision violated the takings clause. The rationale must have been that the statutory deprivation of interest trespassed on a key "incident of ownership" of the fund itself. It denied one of the most important rights incident to the principal of the interpleader fund-its interest-earning capacity. This value is one of the "core" common law property rights that cannot be taken without compensation even when, as in this case, there was prior notice. ${ }^{86}$

84 Webb's Fabulous Pharmacies, 449 U.S. at 164 (emphasis added).

${ }^{86}$ Logan, 455 U.S. at 431, and cases cited therein; Annot. at 57 L.Ed.2d 1254 (cited in note 41). For a general review of the case law in this area, see Annot., Federal Courts: Federal or State Law as Applicable in Determining What Is Property for which Compensation Must Be Paid Upon Its Taking by the Federal Government, 1 A.L.R. Fed. 479 (1972 \& Supp. 1986).

${ }^{86}$ In contrast to the key "incidents of ownership" in Webb's Fabulous Pharmacies, "quasi-property" that is created by purely private contractual arrangements does not constitute a core common law right, and under certain circumstances it may be taken pursuant to a notice statute. In Pension Ben. Guar. Corp., 106 S.Ct. 1018, for example, the Court held that a purely contractual limitation on the extent of liability of an employer withdrawing from a private multi-employer pension plan could be constitutionally modified by a federal statute requiring such an employer to pay his proportionate share of the plan's unfunded, vested benefits. The Court applied the three factors (including "investment-backed expectations") enumerated in Penn Central, 438 U.S. at 124, to determine whether an uncompensated taking had occurred.

The result in Pension Ben. Guar. Corp., however, is distinguishable from takings of yet- 
The Court's failure to consider whether the Florida statute disturbed the fund owners' reasonable investment-backed expectations also strongly supports the view that "core" common law rights, or key "incidents of ownership," are immune from prospective takings pursuant to a notice statute. These rights are so important that their divestiture from the property interest is sufficient to constitute a taking of the property regardless of "reasonable expectations" and regardless of whether the value of the property is totally destroyed.

There are good reasons to think that trade secrets qualify as the sort of "core" common law rights that, under Webb's Fabulous Pharmacies, may not be taken even with notice. Even more so than the deprivation of interest earnings in the Florida case, the disclosure of trade secrets essentially destroys the property. Loss of interest earnings does not destroy the value of the principal; but, as emphasized above, disclosure destroys the value of the trade secret, for secrecy is what makes a trade secret "property."

The long history of common law protection of trade secrets also supports their status as core common law rights. The earliest English case explicitly protecting trade secrets dates from the early nineteenth century, ${ }^{87}$ and English courts of equity had long recognized the possibility of such protection..$^{88}$ Trade secrets were surely an accepted part of English business practice, and therefore almost certainly of its practical, unrecorded legal practice as well, long before the adoption of the fifth amendment in this country. ${ }^{88}$ The earliest recorded American trade secret case was decided in 1836 in Massachusetts, holding that an exclusive secret of the "art of mak-

to-be-created trade secrets pursuant to a notice statute. The statute upheld in that case effected only a partial taking of the employer's net worth, and the property involved had been created solely by a contractual arrangement between two private parties. The statute "only . . . nullified a contractual provision limiting liability by imposing an additional obligation that is otherwise within the power of Congress to impose." 106 S.Ct. at 1026. Except for the payment requirements, employers could abrogate their legal obligations simply by agreeing with each other that they were not obligated. By contrast, the property rights associated with trade secrets enjoy the blessing of state governments, and it is this blessing that is the primary source of property rights.

s7 Yovatt v. Winyard, 1 Jac. \& W. 394, 37 Eng.Rep. 425 (1820) (protecting recipes for veterinary medicines).

ss See, e.g., Newbery v. James, 2 Mer. 446 (1817) (implying that a misappropriation of a secret for manufacturing pills might give rise to a cause of action); Canham v. Jones, 35 Eng.Rep. 302, 303, 2 V. \& B. 218, 221 (1813) (indicating that a right could be established in a trade secret for a specific medical recipe); Gibblett v. Read, 9 Mod. 459, 460, 88 Eng.Rep. 573,574 (1744) (noting that "physical secrets or nostrums" may be part of an estate).

see, e.g., Canham, 35 Eng.Rep. at 302, 2 V. \& B. at 218 (secret medical recipe sold for 6,000 pounds in 1780 ). 
ing chocolate" was a form of property that could be sold..$^{90}$ In any event, protection for trade secrets is a much older part of American law than many other entitlements to intangible property deemed worthy of constitutional protection, such as a driver's license, a high school education, and utility service. ${ }^{91}$ In fact, it is older than all of the forms of intangible property cited by the Court in recognizing a property right in a tort claim. ${ }^{92}$ Thus, protection of trade secrets is one of the "core" common law rights, one that a federal statute cannot unilaterally abrogate.

The Monsanto Court quoted extensively from Webb's Fabulous Pharmacies, but it failed to give analogous protection against prospective takings of yet-to-be-created trade secrets pursuant to a notice statute, because it failed to appreciate the indivisibility of the secrecy stick. Once that indivisibility is realized, the conclusion that notice cannot excuse a taking of the property is inevitable.

\section{The Monsanto "Bargain": An Unconstitutional Condition}

In addition to examining the question of investment-backed expectations, the Court in Monsanto supported its holding that the post-1978 FIFRA disclosure provisions did not constitute a taking by noting that "a voluntary submission of data by an applicant in exchange for the economic advantages of a registration can hardly be called a taking." Monsanto bought a license to sell pesticides in the United States and paid for it by disclosing its data pursuant to the post-1978 statute. This argument might be persuasive if the bargain recognized by the Court were of the type that two parties, negotiating freely, could be expected to reach. But the "bargain" in Monsanto was not voluntary.

The involuntary nature of the exchange in Monsanto is clear in light of the consequences Monsanto would have faced if it had refused to submit the data: the company could not have marketed its pesticides in the United States if it had so refused. The penalty for refusal to comply with FIFRA amendments was loss of a preexisting right that Monsanto certainly possessed between 1972 and 1978-the right to sell pesticides in the United States without be-

\footnotetext{
so Vickery v. Welch, 36 Mass. 523 (1837).

92 See note 36 above.

${ }^{82}$ See Logan, 455 U.S. at 431.

${ }^{93} 467$ U.S. at 1007.
} 
ing forced to give up its trade secrets. ${ }^{94}$ In effect, the 1978 FIFRA conditions the receipt of a valuable government benefit-the right to sell-upon applicants' willingness to forego their fifth amendment rights.

The government's ability to compel disclosure of trade secrets in such a fashion is limited by the unconstitutional conditions doctrine, which prevents the government from conditioning the receipt of public benefits on an individual's willingness to waive his constitutional rights..$^{95}$ Seen in this light, the "exchange" approved by Justice Blackmun looks more like extortion-of the "Your money or your life variety." "96 The unconstitutional conditions doctrine, as currently interpreted ${ }^{97}$ must prevent the government

' Justice O'Connor believed Monsanto enjoyed this right before 1972 as well. Id. at 1021 (O'Connor, J., concurring in part and dissenting in part).

Although Monsanto still may market pesticides internationally without subjecting itself to post-1978 FIFRA regulations, see id. at $1007 \mathrm{n} .11$., this does not prove that disclosure under FIFRA is not a taking. The post-1978 FIFRA still unconstitutionally conditions a previously conferred government benefit-the right to sell in the United States-upon Monsanto's waiver of its fifth amendment rights.

${ }^{23}$ An early expression of the unconstitutional conditions doctrine is found in Frost \& Frost Trucking Co. v. Railroad Commission, 271 U.S. 583, 593-94 (1926):

It would be a palpable incongruity to strike down an act of state legislation which [denies] the citizen of rights guaranteed by the federal Constitution, but to uphold an act by which the same result is accomplished under the guise of a surrender of a right in exchange for a valuable privilege which the state threatens otherwise to withhold. A more recent expression may be found in Sindermann, 408 U.S. at 597: "even though a person has no 'right' to a valuable government benefit and even though the government may deny him the benefit for any number of reasons, [it cannot do so] on a basis that infringes his constitutionally protected interests." See also Carter v. Kentucky, 450 U.S. 288, 301 (1981); Branti v. Finkel, 445 U.S. 507, 514 (1980); Elrod v. Burns, 427 U.S. 347, 359 (1976).

${ }^{\circ}$ See Frank H. Easterbrook, Insider Trading, Secret Agents, and the Protection of Information, $1981 \mathrm{~S}$. Ct. Rev. 309, 348. In Monsanto, the coercive "exchange" is more like "your property or the value of your property." Monsanto can either give trade secret data to EPA subject to FIFRA disclosure or keep the data secret and give up its economic value-the ability to register and sell the product in the U.S. (which puts the owner in the same position as a trade secret thief enjoined from using the secret). Either way, Monsanto is made worse off by the government's "offer".

${ }^{97}$ For a skeptical view that there may be no unconstitutional conditions doctrine after Buckley v. Valeo, 424 U.S. 1 (1976), see Easterbrook, 1981 S. Ct. Rev. at 348 (cited in note 96). Shortly after Buckley $v$. Valeo, however, the Court reaffirmed the unconstitutional conditions doctrine in Elrod, 427 U.S. at 359, in which it relied on Sindermann, 408 U.S. 593, to strike down conditions on political patronage employment that interfered with the employees' exercise of their first amendment rights. The Court again explicitly relied on the unconstitutional conditions doctrine in Branti, 445 U.S. at 514. Moreover, lower courts continue to recognize the unconstitutional conditions doctrine. See, e.g., Grossart v. Dinaso, 758 F.2d 1221, 1225 n.1 (7th Cir. 1985) ("The unconstitutional condition line of analysis . . . is unequivocally accepted by the Branti and Elrod Courts"); Barnes v. Bosley, 745 F.2d 501, 505 (8th Cir. 1984); Parks v. Watson, 716 F.2d 646, 651-52 (9th Cir. 1983) (condition imposed on zoning change held unconstitutional); Bullfrog Films, Inc. v. Wick, 646 F.Supp. 492, 502 (C.D. Cal. 1986) (striking down conditions placed on right to import films duty-free estab- 
from using such coercive offers to obtain complete waivers of constitutional rights.

\section{A Coherent Understanding of Monsanto}

Monsanto looked to state law to determine whether the trade secrets in question were property within the meaning of the fifth amendment. Yet the Court seemed to decide that disclosure of such secrets would not constitute a taking unless the same federal statute that called for disclosure also provided explicit assurance of confidentiality. However, to be coherent, the decision must be read differently.

The Court should have deemed the disclosures in Monsanto to be takings. Takings clause jurisprudence applied to the peculiar features of trade secrets teaches that: (1) any federal interference with existing trade secrets that are protected by state law will constitute a complete taking, for which a public purpose and just compensation are required; and (2) prospective takings of trade secrets pursuant to a notice statute interfere with a "core" common law right, and therefore also come within the fifth amendment's proscription. A proper application of Monsanto should reflect these principles and those parts of the decision that do not conform should be limited to the Court's specific assumptions and the particular facts of the case.

One way to reconcile Monsanto's recognition of state-defined trade secret property rights with these principles would be to require explicit federal statutory protection of a property right only where a finding has been made that no legitimate expectation of protection could arise from some other source, such as state law or past agency practice. Unfortunately, the lower courts have read Monsanto to require that explicit statutory protection always be present in order to recognize a property interest, without even considering whether, in some cases, a submitter of data could have reasonably formed an expectation of protection upon some other basis. ${ }^{98}$

It may be argued that the suggested reading of Monsanto proves too much because it would interfere with federal and state regulation of such matters as food and drug labeling, and with toxic substance disclosure statutes such as the New Jersey Right to

lished by treaty); Abraham v. Pekarski, 537 F.Supp. 858, 864 (E.D. Pa. 1982) (political patronage firing). The unconstitutional conditions doctrine clearly remains vital despite Buckley $v$. Valeo.

${ }^{\text {8s }}$ See note 57 above. 
Know Act, discussed in New Jersey State Chamber of Commerce v. Hughey. ${ }^{99}$ As for food and drug ingredients, if they were understood as trade secrets, they would be entitled to the protection advocated here. However, after a century of federal and state food and drug regulation, it is not likely that a coherent argument could be made that the ingredients (as opposed to manufacturing methods) of currently marketed foods and drugs are trade secrets protected by state law. The protracted, general acquiescence in disclosure of confidential information of the ingredients of products, such as food and drugs, already on the market may be thought of as analogous to allowing adverse possession of one's real property. Both state trade secret law and the Uniform Trade Secrets Act recognize that failure to protect a trade secret can result in its loss. ${ }^{100}$ However, such a waiver cannot apply automatically to newly developed products placed on the market for the first time.

In Monsanto, the Court operated under the assumption that pesticide registrants were well aware of the substantial possibility that the federal government "would find disclosure to be in the public interest." 101 In essence, the Court simply assumed that the trade secret baseline was like that of food and drug ingredients, long since consensually waived as state property interests. Justice O'Connor sharply criticized the Court's assumptions concerning the pre-1972 baseline and would have remanded to the district court because "the extent of Monsanto's pre-1972 expectations ... is a heavily factual question."102

As for environmental and public health statutes, strengthened protection of trade secrets would not hamper their operation severely. The disclosure provisions of these statutes are fairly narrow and tend not to invade protected trade secrets significantly, ${ }^{103}$ and they are justified by strong public health considerations. Even if these disclosure requirements were held to effect takings, many of them are not critical to the enforcement of the acts-for example,

900 F.Supp. at 609-12.

${ }^{100}$ See Restatement of Torts $\S 757$, comment b (1939); Uniform Trade Secrets Act, $\S$ II(4), 14 U.L.A. 542 (West 1980) (both requiring "efforts that are reasonable under the circumstances to maintain its secrecy").

101 Monsanto, 467 U.S. at 1008-09.

102 Id. at 1024 (O'Connor, J., concurring in part and dissenting in part).

${ }_{103}$ Most of these statutes are limited in two ways: they usually require disclosure of only safety-related data, and even where the identity of specific product constituents must be disclosed, concentration data are not always required. These statutes may inform the public that a particular breakfast cereal contains sugar, but they do not allow anyone to discover how the cereal is manufactured. 
the disclosure provisions of the Clean Air $\mathrm{Act}^{104}$ and the various "Right to Know" acts cited in the Solicitor General's brief on behalf of the EPA in Monsanto, ${ }^{105}$ are not critical to the enforcement of those statutes. ${ }^{108}$

The situation is far different, however, with generalized disclosure statutes such as the Freedom of Information Act. Such statutes invade trade secrets to a far greater degree than do specific public health statutes, and they lack an equivalent compelling justification for disclosure. The next section scrutinizes the practice of disclosure under FOIA in light of the takings clause.

\section{Federal Disclosure Statutes and the Fifth Amendment}

The takings issue in Monsanto-that disclosure of data could effect a compensable taking of property by disclosing trade secrets protected as property under state law-arises whenever a government agency obtains information that the agency might disclose to third parties. Federal and state disclosure statutes, like the Freedom of Information Act, are the most important mechanisms through which such disclosure can occur. ${ }^{107}$ If courts read Monsanto coherently and refuse to allow the federal statute's own provisions to define what constitutes a taking, FOIA disclosures will

10442 U.S.C. \& 7607(a)(1) (1982).

${ }^{108}$ Brief of Appellant Environmental Protection Agency 40 n. 29, reprinted in U.S. Supreme Court Briefs and Records, 467 U.S. 986 (1984).

${ }^{106}$ In most cases, the enforcement activities authorized by the statutes depend on agency knowledge of the information the agencies collect. For instance, the FDA could monitor the safety of food additives without disclosing them to the public.

${ }^{107}$ This comment discusses only the federal Freedom of Information Act. However, many states have enacted similar statutes. In Illinois, for example, the state Freedom of Information Act, Ill. Rev. Stat., ch. 116, par. I 201-11 (1985), went into effect on July 1, 1984. It appears to differ from the federal statute in a number of ways: most notably, the Illinois statute specifies that it should not be used to "further a commercial enterprise." Id. at I 201. Its trade secret exemption is as follows: "Trade secrets and commercial or financial information obtained from a person or business where such trade secrets or information are proprietary, privileged, or confidential, or where disclosure of such trade secrets or information may cause competitive harm." Id. at I 207(g). This definition seems to incorporate the "substantial competitive harm" standard of the federal FOIA case law discussed below at notes $140-42$, but the test is presented as enlarging rather than limiting the scope of the exemption: the statute covers trade secrets or information whose disclosure would cause competitive harm rather than imposing a requirement of competitive harm upon the definition of a trade secret. See generally Chicago Lawyer 1985 FOIA Guide, Chicago Lawyer 5, col. 1 (Oct. 1985). In the first case interpreting the Illinois FOIA, however, the court observed in dicta that the legislative history of the Illinois FOIA indicated an intent to import federal FOIA decisions into Illinois substantive law. Roulette v. Dept. of Cent. Managements, 141 Ill.App.3d 394, 490 N.E.2d 60, 64 (1986). That interpretation seems irreconcilable with the language of the statute itself. Thus, the future direction of Illinois' FOIA law is uncertain. 
be found to violate the fifth amendment in many cases. Even if courts follow the prevailing, inconsistent interpretation of Monsanto and make trade secret protection contingent on a federal guarantee of confidentiality, the state law definition of property still will limit an agency's ability to disclose information under FOIA.

\section{A. State Law Definitions of Trade Secret Property}

Monsanto looked to state law in the first instance to define trade secret rights. Thus it will be useful first to examine briefly how various states define and protect trade secrets. ${ }^{108}$ In particular, this section examines state law treatment of confidential business information, in order to lay the groundwork for the comparisons to the D.C. Circuit's treatment of similar data in its FOIA decisions.

Monsanto suggests that most states that subscribe to the $R e-$ statement of Torts definition of trade secrets ${ }^{109}$ endow trade secrets with the attributes of property. ${ }^{110}$ Even before Monsanto, practically all jurisdictions had recognized the property status of trade secrets. ${ }^{111}$ Trade secrets are thus widely recognized as property, and there is no indication that they will soon lose this status.

A more controversial issue, however, is whether a particular type of information constitutes a trade secret that state law recognizes as property. ${ }^{112}$ In particular, while all jurisdictions provide some protection for industrial trade secrets of a technical nature, there is a divergence of views as to the protectability of confidential business information.

103 This examination raises the question of which state's law will apply. This complex choice of law problem is beyond the scope of this comment. It would appear, however, that the interest analysis used by the U.S. District Court for the District of Columbia, see, e.g., Keene Corp. v. Insurance Co. of North America, 597 F.Supp. 934, 938 (D. D.C. 1984), would lead to the result that the situs of the trade secret's use or of its owner, rather than the place of the litigation, controls. Either the state of ownership or of use would have a greater interest in the trade secret than the forum state. See Wearly v. F.T.C., 462 F.Supp. 589, 59495 n.6 (D. N.J. 1978) (law to be used in determining rights in a trade secret is, as with other intangible property interests, that of the situs of the owner of the interest).

${ }^{100}$ Restatement of Torts $\S 757$ (1939) ("First Restatement"), discussed below at notes 113-23 and accompanying text.

110467 U.S. at 1016.

"11 See Milgrim, 1 Trade Secrets, § 1.01[2] (cited in note 4), and cases cited therein. This common law recognition is bolstered in thirty-eight states by explicit statutory protection for trade secrets. Id. at App. B, B-1.

${ }^{112}$ See id. $\S 2.09$ ("Ithere are] many instances, particularly with reference to customer lists and business (as opposed to industrial) secrets, where different jurisdictions reach contrary conclusions concerning trade secret status with respect to essentially identical matters"). 
The majority of states derive their law of trade secrets from section 757 of the first Restatement of Torts, which contains a proscription against "disclosure or use of another's trade secret" as part of its discussion of tortious interference with business relations. ${ }^{113}$ The First Restatement defines "trade secret" as "any formula, pattern, device, or compilation of information which is used in one's business, and which gives him an opportunity to obtain an advantage over competitors who do not know or use it."114 Further, "it is not simply information as to single or ephemeral events in the conduct of the business, as, for example, the amount or other terms of a secret bid for a contract or the salary of certain employees. . . . A trade secret is a process or device for continuous use in the operation of the business."115 Under the First Restatement, trade secret protection generally extends to confidential business information-for example, price and cost information-if it is clearly shown that the information actually had objective value dependent on its secrecy and that it was treated confidentially by its owner. ${ }^{116}$

113 First Restatement $\S 757$ (cited in note 101). The authors of the Restatement (Second) of Torts declined to include a section on trade secrets because trade regulation had evolved into a separate branch of law that was no longer based primarily on tort principles. Restatement (Second) of Torts at 1 (1979). See also Milgrim, 1 Trade Secrets, $\S 2.01 \mathrm{n} .2$ (cited in note 4). Twenty-nine states and the District of Columbia have used at least part of the section 757 definition of a trade secret. However, several of these states, as noted at note 117 below, have since adopted the statutory definition in the Uniform Trade Secrets Act. Courts also sometimes mix parts of the section 757 definition with other definitions. See, e.g., Hayden's Sport Center, Inc. v. Johnson, 109 Ill.App.3d 1140, 1146-47, 441 N.E.2d 927, 932 (1982) (using parts of the section 757 definition together with an older definition taken from the Corpus Juris Secundum, described at text accompanying note 122 below). Even the adoption of a statutory definition may not eliminate this practice. See, e.g., American Totalisator Co. v. Autotote Ltd., Civ. No. 7268, slip op. (Del. Ch. Aug. 8, 1983) (referring to decisions utilizing law of Pennsylvania, Oregon, Virginia, and Oklahoma to aid in defining the term "trade secret," despite the existence of a statutory definition in Delaware). Therefore, in each case care must be taken to look beyond references to section 757 to the actual, substantive criteria in use, which may vary significantly even among the states that have adopted section 757 .

${ }_{114}$ First Restatement $\S 757$, comment b (cited in note 100). A trade secret "may be a formula for a chemical compound, a process of manufacturing, treating or preserving materials, a pattern for a machine or other device, or a list of customers." Id. For a discussion of how to identify a trade secret under section 757, see Peter C. Quittmeyer, Trade Secrets and Confidential Information under Georgia Law, 19 Ga. L. Rev. 623, 635 n.51 (1985).

118 First Restatement $\$ 757$, comment b. The First Restatement also contains a provision for protection of "ephemeral data": "One who, for the purpose of advancing a rival business interest, procures by improper means information about another's business is liable to the other for the harm caused by his possession, disclosure, or use of the information." Id. $\S 759$. For a description of the limited use this provosion has seen, see Ramon F. Klitzke, The Uniform Trade Secrets Act, 64 Marq. L. Rev. 277, 286 n.53 (1980).

${ }^{116}$ See, e.g., Sigma Chemical Co. v. Harris, 586 F.Supp. 704, 709 (E.D. Mo. 1984), for 
Eleven other states have adopted substantially identical versions of the Uniform Trade Secrets Act (UTSA). ${ }^{117}$ The UTSA contains the following definition of a trade secret:

(4) "Trade secret" means information, including a formula, pattern, compilation, program, device, method, technique, or process, that:

(i) derives independent economic value, actual or potential, from not being generally known to, and not being readily ascertainable by proper means by, other persons who can obtain economic value from its disclosure or use, and

(ii) is the subject of efforts that are reasonable under the circumstances to maintain its secrecy. ${ }^{118}$

Unlike the Restatement's definition, the UTSA does not require that a secret be "continuously used in one's business" in order to qualify as a trade secret. ${ }^{119}$ Further, by defining a trade secret as "information," the UTSA establishes a single standard for both business and technical secrets. ${ }^{120}$

Georgia, on the other hand, exemplifies the opposite extreme from the UTSA states with regard to trade secret protection for confidential business information. Georgia has explicitly rejected the section 757 definition ${ }^{121}$ and instead uses an older definition derived from the Corpus Juris Secundum: " 'A trade secret, within the rules pertaining to the rights which can be protected by an injunction, is a plan, process, tool, mechanism, or compound, known only to its owner and those of his employees to whom it must be confided in order to apply it to the uses intended." "'122 Thus, Georgia courts have uniformly refused to recognize price and

an illustration of the application of section 757 to confidential business information. For further examples, see Milgrim, 1 Trade Secrets at $\$ 2.09$ [8][b] n.449 (cited in note 4).

11714 U.L.A. 541 (1980). For the text of the Act, see Milgrim, 3 Trade Secrets at App. A (cited in note 4). The following states have adopted the UTSA: Minnesota, Arkansas, Kansas, Louisiana, Idaho, Washington, Indiana, Delaware, Connecticut, North Dakota, and California. Id. at 3 App. AA, AA-2.

11814 U.L.A. 542 (1980).

11. Compare First Restatement $\S 757$, comment b.

${ }^{120}$ For an example of how the UTSA protects confidential business information as a trade secret, see American Totalisator, Civ. No. 7268, slip op. For the opposing view that business information is not a trade secret, see notes 121-23 and accompanying text below. 121 See Textile Rubber \& Chemical Co. v. Shook, 243 Ga. 587, 589-90, 255 S.E.2d 705, 707-08 (1979).

122 Taylor Freezer Sales Co., Inc. v. Sweden Freezer Eastern Corp., 224 Ga. 160, 164, 160 S.E.2d 356, 359 (1968), quoting 43 C.J.S. $\& 148$ at 750 (1955). 
cost information as trade secrets. ${ }^{123}$

\section{B. The Freedom of Information Act Under a Coherent View of Monsanto}

FOIA allows any person to obtain access to the records of any federal agency, subject only to compliance with the formalities of the statute. FOIA does, however, explicitly protect trade secrets in the custody of the federal government. ${ }^{124}$ Section (b)(4) allows federal agencies responding to FOIA requests to exercise their discretion and refuse to disclose certain types of information, including "trade secrets and commercial or financial information obtained from a person and privileged or confidential."125 Even information within the scope of exemption of (b)(4) may be disclosed pursuant to agency discretion. ${ }^{126}$ However, the Administrative Procedure Act (APA) ${ }^{127}$ provides for judicial review of actions taken pursuant to agency discretion; $;^{128}$ and if information falls within the (b)(4) exemption, its disclosure may be an abuse of that discretion. ${ }^{129}$ Thus, the APA provides the primary mechanism by which submitters of data may challenge an agency decision to release information. ${ }^{130}$

Because FOIA includes special venue provisions that tend to

${ }^{123}$ Taylor Freezer Sales, 160 S.E.2d at 358-60. For other cases reaching the same conclusion, see Textile Rubber, $243 \mathrm{Ga}$. at 592, 255 S.E.2d at 709; Howard Schultz \& Assocs. of the Southeast, Inc. v. Broniec, 239 Ga. 181, 187, 236 S.E.2d 265, 270 (1977); Vendo Co. v. Long, 213 Ga. 774, 777, 102 S.E.2d 173, 175 (1958).

124 The FOIA disclosure mandate overrides any promises of confidentiality the agency may have made. See, e.g., Robles v. Envir. Protection Agency, 484 F.2d 843, 846 (4th Cir. 1973); Racal-Milgo Gov. Systems, Inc. v. Small Bus. Admin., 559 F.Supp. 4, 6 (D. D.C. 1981). But see Wearly v. Fed. Trade Comm., 462 F.Supp. 589, 600 n.13 (D. N.J. 1978) (suggesting that the FOIA exemptions protecting trade secrets should be read as mandatory rather than as discretionary). While the Trade Secrets Act, 18 U.S.C. $\S 1905$, prohibits government employees from disclosing trade secrets, the Monsanto Court refused to hold that this was a promise of confidentiality. 467 U.S. at 1008-09.

1285 U.S.C. $\S 552$ (b)(4).

${ }^{128}$ Gulf \& Western Indus., Inc. v. United States, 615 F.2d 527, 532 (D.C. Cir. 1980).

${ }_{127} 5$ U.S.C. $\$ \S 701$ et seq. (1982).

${ }^{128}$ Id. $\$ 706$ (2)(A).

${ }^{129}$ See, e.g., Worthington Compressors, Inc. v. Costle, 662 F.2d 45, 54 (D.C. Cir. 1981); United Technologies Corp. v. Dept. of Health and Human Serv., 574 F.Supp. 86 (D. D.C. 1983); J.H. Lawrence Co. v. Smith, 545 F.Supp. 421 (D. Md. 1982).

${ }^{130}$ Such a challenge is termed a "reverse-FOIA action." See James O'Reilly, 1 Federal Information Disclosure $\$ 10.06$ (1985), for a detailed account of the steps required to bring a reverse-FOIA action. For a discussion of reverse-FOIA actions in the trade secret context, see Note, Constitutional Limitations on Government Disclosure of Trade Secret Information, 56 Ind. L. J. 347, 350-54 (1981). 
encourage suits in the D.C. Circuit, ${ }^{131}$ and because both of FOIA's most frequent users-public interest lobbying groups and federal agencies-are concentrated in the Washington, D.C. area, nearly all of the more than 100 cases interpreting exemption (b)(4) have been decided within the D.C. Circuit. ${ }^{132}$ Therefore, the D.C. Circuit's view of the extent of protection that exemption (b)(4) affords to trade secrets, and its view of the meaning of the terms "trade secret" and "commercial or financial information," are most important to the exemption's working.

Although commentators discussing the language of exemption (b)(4) before its enactment had noted its ambiguity, ${ }^{133}$ the D.C. Circuit settled on the following interpretation of the exemption's scope:

(1) trade secrets, or

(2) commercial or financial information that was obtained from a person and that is privileged or confidential. ${ }^{134}$

This interpretation has two serious flaws. It draws a spurious distinction between "trade secrets" and "commercial or financial information,"13s and it underprotects the latter by imposing additional requirements-“obtained from a person" and "privileged or confidential"-for "commercial or financial information" to qualify for the protection of exemption (b)(4). Thus, exemption (b)(4) as interpreted by the D.C. Circuit conflicts with the definition of trade secrets prevailing in forty-nine of the fifty states. ${ }^{136}$ Indeed, by 1982 , the D.C. Circuit had completely excluded price and cost information from its definition of "trade secret" and in effect had abandoned the body of state law defining trade secrets. Second,

131 See 5 U.S.C. $\$ 552$ (a)(4)(B). This provision allows an action to be brought against an agency in the plaintiff's home district, or in the district where the agency records are located, or in the District of Columbia.

132 See Annot., What Constitutes "Trade Secrets and Commercial or Financial Information," 21 A.L.R. Fed. 224 (1974 \& Supp. 1985).

${ }^{133}$ For a discussion of views at the time of enactment, see U.S. Department of Justice, Attorney General's Memorandum on the Public Information Section of the Administrative Procedure Act (1967); Kenneth Culp Davis, The Information Act: A Preliminary Analysis, 34 U. Chi. L. Rev. 761 (1967).

1s4 National Parks and Conservation Assoc. v. Morton, 498 F.2d 765, 766 (D.C. Cir. 1974). This interpretation of the statutory language is now "reasonably certain" as a result of subsequent D.C. Circuit cases. Milgrim, 1 Trade Secrets, § 6.02[A][2] (cited in note 4).

$2 s 5$ The vast majority of states' trade secret laws do not make such a distinction, and most states include secret business information in their definition of trade secrets. See text accompanying notes $113-20$ above.

136 See section IV-A above. Only the Georgia approach resembles the D.C. Circuit's view that confidential business information cannot. constitute a trade secret. 
overlooking state law, the D.C. Circuit has developed its own idiosyncratic definition of technical trade secrets that is much narrower than the definitions used in most states. As a result, operation of the FOIA often invades fifth amendment protections for trade secrets that exist under a coherent view of Monsanto.

1. Current FOIA treatment of confidential business information. The seminal case dealing with the meaning of exemption (b) (4) in the context of business information is National Parks \& Conservation Association v. Morton. ${ }^{137}$ In National Parks, the D.C. Circuit observed that FOIA contains no definition of the term "confidential" for purposes of determining the protection of confidential business information under the second half of $(b)(4)$. The court then noted that past decisions had been influenced by the 1965 Senate Report on the legislation, which emphasized that the key test was whether the information "would customarily not be released to the public by the person from whom it was obtained."138 While retaining this requirement, National Parks fabricated, out of whole cloth, another semi-objective test:

[C]ommercial or financial matter is "confidential" for purposes of the exemption if disclosure of the information is likely to have either of the following effects: (1) to impair the Government's ability to obtain necessary information in the future; or (2) to cause substantial harm to the competitive position of the person from whom the information was obtained. ${ }^{139}$

Thus, the D.C. Circuit has interpreted section (b)(4) of FOIA to mean that federal agencies have discretion to protect confidential business information such as secret cost and pricing data only where disclosure would interfere with government operations or cause "substantial competitive harm" to the supplier. To establish that such harm will occur, the supplier must demonstrate both the existence of actual competition and the currency of the confidential information. ${ }^{140}$ Because the deterrence and substantial competitive harm tests are inconsistent with rights protected by state

${ }^{137} 498$ F.2d 765 (D.C. Cir. 1974).

${ }^{138}$ Id. at 770, citing S. Rep. No. 813, 89th Cong., 1st Sess. 9 (1965).

139498 F.2d at 770 (footnote omitted). The first test is usually referred to as the "deterrence" requirement, and the second is called the "substantial competitive harm" requirement. 1980).

${ }^{140}$ Braintree Electric Light Dept. v. Dept. of Energy, 494 F.Supp. 287, 291 (D. D.C. 
trade secret laws, ${ }^{141}$ agency disclosure of business information pursuant to these guidelines effects a taking of property under the proper reading of Monsanto.

2. Current FOIA treatment of technical trade secrets. Not long after the National Parks decision, the D.C. Circuit narrowed even further the scope of protection accorded technical trade secrets under (b)(4),,$^{142}$ and in 1983, it broke definitively with the law of most states in Public Citizen Health Research Group $v$. Food \& Drug Administration. ${ }^{143}$ In Public Citizen, the court reasoned that Congress would have looked to interpretations of the Trade Secrets Act in framing exemption (b)(4). Therefore, the court concluded, Congress must have intended to limit trade secret protection to a scope no broader than the construction of the Act set forth in the early case of United States ex rel Norwegian Nitrogen Products Co. v. United States Tariff Commission. ${ }^{144} \mathrm{Al}-$ though the law of most states is now quite different from the view taken in Norwegian Nitrogen, ${ }^{145}$ the D.C. Circuit in Public Citizen proceeded to formulate its definition of a trade secret based on that case: "a secret, commercially valuable plan, formula, process, or device that is used for the making, preparing, compounding, or processing of trade commodities and that can be said to be the end product of either innovation or substantial effort."146

This definition not only excludes business information from the ambit of "trade secrets," following the National Parks reading of exemption (b)(4), but it also imposes a requirement of innovation not unlike that for a patent. Thus, the D.C. Circuit's definition of a technical trade secret conflicts with state law. ${ }^{147}$ While

142 See text accompanying notes $113-20$ above.

142 See Worthington Compressors, 662 F.2d at 51 (appearing to apply "substantial competitive harm" test to disclosure of trade secrets).

is 704 F.2d 1280, 1287 (D.C. Cir. 1983).

1446 F.2d 491 (D.C. Cir. 1925). In that case, the disputed information consisted of data on certain elements of the cost of foreign nitrate fertilizer production, such as electric power costs, which the commission had requested for use in enforcing tariff regulations. Technical trade secrets were not involved. The Norwegian Nitrogen court was interpreting a predecessor to the Trade Secrets Act. For a discussion of Norwegian Nitrogen, see Mark Q. Connelly, Trade Secrets and Smokescreens: A Legal and Economic Analysis of Government Disclosures of Business Data, 1981 Wis. L. Rev. 207, 230.

${ }^{145}$ Only Georgia retains a view of trade secrets that is really consistent with the Norwegian Nitrogen definition.

148 Public Citizen, 704 F.2d at 1288.

117 While some state courts have required an element of discovery for an industrial trade secret, this element arises more from practical concerns incidental to proof of secrecy rather than from the public policy considerations underlying the patent law requirement of novelty. See Milgrim, 1 Trade Secrets, $\S 2.08$ [2] (cited in note 4). The majority view is that 
this variance is partially explained by the D.C. Circuit's assumption that federal common law should be used to define "trade secret" in the FOIA context, ${ }^{148}$ that assumption itself is inconsistent with the Supreme Court's more recent position in Monsanto-that federal law cannot redefine property rights already established by state law. ${ }^{140}$

\section{FOIA Under the Internally Inconsistent Reading of Monsanto}

Even under the inconsistent reading of Monsanto, which allows Congress to redefine the property status of trade secrets, courts must recognize that FOIA-mandated disclosures of trade secrets protected by state law are takings. The reasons are simple: like the 1972-78 FIFRA, FOIA explicitly promises that trade secrets in the custody of the federal government will remain secrets.

The inconsistent reading of Monsanto requires an explicit as-

the prior state of the art is not relevant to trade secret protection. Id. at $\S 2.08$ [3]. Certainly the Public Citizen requirement of "innovation or substantial effort" is not found in most state trade secret decisions.

${ }^{148}$ In light of the source of the Public Citizen definition of "trade secret," it is reasonable to conclude that the D.C. Circuit's interpretation of the term is a matter of federal common law rather than D.C. law analogous to state law.

In United Steelworkers of America v. Auchter, 763 F.2d 728 (3d Cir. 1985), the United Steelworkers sought review of a definition of trade secrets to be applied to an exemption from the Occupational Safety and Health Act's requirement that workers be informed of potential hazards (notably chemical hazards) in the workplace. The Act provided protection for information that might constitute or reveal a trade secret "referred to in section 1905 of Title 18." 29 U.S.C. $\S 664$ (1982). The Third Circuit cited Public Citizen for the proposition that the definition of "trade secret" in "other [federal] regulatory contexts" need not be the same as that afforded by state law. Auchter, 763 F.2d at 741. Thus, it seems that other circuits also believe the D.C. Circuit's views on FOIA reflect federal common law rather than D.C. law analogous to state law.

149 Treatment of trade secrets as "core" common law rights, see section III-B above, inevitably leads to the conclusion that current FOIA disclosure practices are unconstitutional. Invasions of "core" common law rights are constitutional only where there has been "a compelling showing of necessity or a provision for a reasonable alternative remedy." Pruneyard, 447 U.S. at 94 (Marshall, J., concurring). FOIA provides no alternative remedy-that is, no compensation system-at all. Therefore, FOIA trade secret disclosures must be justified only by a "compelling showing of necessity." That is, disclosure must be necessary to effectuate the FOIA's purpose-exposing the federal government's workings to public scrutiny. See discussion of FOIA purposes in O'Reilly, 1 Federal Information Disclosure at $\$ \S 2,4.03$ (cited in note 130). Disclosure of the private trade secrets of persons who happen to be dealing with the federal government will not, in most instances, further this goal. Certainly it is difficult to see how such disclosure in the general FOIA context would be compellingly necessary, in the sense that it could be argued that public health necessarily compelled the disclosure of Monsanto's health and safety data. The standard of "compelling necessity" clearly requires more than the "conceivable public purpose" standard applied to ascertain the public or private character of a taking. 
surance of protection in the acquiring statute-or more carefully stated, a finding that past practice could have produced a reasonable investment-backed expectation of confidentiality. ${ }^{150}$ FOIA provides this, because whatever Congress's intent might have been with respect to the "commercial or financial information" provision of section (b)(4), Congress in that provision almost certainly intended to import the existing state law interpretations of the legal term "trade secret."151 Thus, like the 1972-1978 FIFRA, FOIA intended to continue state law protection for trade secrets.

FOIA also lacks whatever elements of a "bargain" were sufficient to save FIFRA's disclosure provisions. The Monsanto Court concluded that the post-1978 FIFRA provisions effectively allowed pesticide manufacturers to "buy" a license to sell pesticides in the United States by disclosing the data sought by the EPA. ${ }^{152}$ It was this "exchange" that allowed the Monsanto Court to conclude that disclosures under the post-1978 FIFRA did not violate the fifth amendment. ${ }^{163}$ By contrast, trade secret data, particularly in the form of price and cost information, find their way into federal agencies by a myriad of paths, few of which involve any quid pro quo for submission of data. ${ }^{154}$ Therefore, FOIA disclosures cannot be justified by means of the "bargain" rationale used in the case of disclosures under the post-1978 FIFRA.

\section{ConcLusion}

Applied correctly so as to achieve both internal consistency and harmony with other takings clause decisions, Monsanto establishes that state laws recognizing trade secrets as property trigger fifth and fourteenth amendment protection for trade secrets. Courts must substitute state law trade secret definitions for the D.C. Circuit's federal common law definition, and they must inter-

1 so See note 57 above.

${ }^{151}$ See O'Reilly, 1 Federal Information Disclosure at $\$ 14.06 \mathrm{n} .1$ (cited in note 130); O'Reilly, Trade Secrets: Asleep at the Switch?, 12 Am. Intell. Prop. L.A. Q. J. 13, 15 (1984). See also note 104 above.

132467 U.S. at 1006-07.

iss Id. at 1007 .

Ist Few, if any, of these channels are consensual even in the sense that the post-1978 FIFRA was consensual. And even where other statutes provide guarantees, FOIA may negate them through bureaucratic carelessness. See Monsanto Co. v. Ruckelshaus, 753 F.2d 649 (8th Cir. 1985) (describing the improper disclosure of trade secret information pursuant to a FOIA request). 
pret federal disclosure statutes such as FOIA to effectuate that protection, which even the narrow reading of Monsanto requires. Monsanto should be read as mandating full protection to the core common law right of trade secret protection.

John C. Janka 